\title{
Social Media, Populism, and COVID-19: Weibo Users' Reactions to Anti-Chinese Discourse
}

\author{
Theresa Catalano ${ }^{1}$, Peiwen Wang ${ }^{1}$ \\ ${ }^{1}$ Department of Teaching, Learning and Teacher Education, University of Nebraska-Lincoln, Lincoln, United States \\ Correspondence: Theresa Catalano, University of Nebraska-Lincoln, Henzlik Hall 118, Lincoln, NE 68588, United \\ States.
}

Received: September 28, 2021

Accepted: October 20, 2021

Online Published: October 23, 2021

doi:10.11114/smc.v9i2.5388

URL: https://doi.org/10.11114/smc.v9i2.5388

\begin{abstract}
US government communication about the COVID-19 pandemic, particularly the 'Chinese virus' discourse adopted by Donald Trump and his administration, has led to real-world violence and triggered heated discussions across social media sites, including Sina Weibo (aka Chinese Twitter). The current study explores the relationship between populism and social media by examining how Sina Weibo users respond to Trump's communication on the virus. Employing multimodal critical discourse analysis, we examine both visual and verbal strategies used to build counter-discourses that challenge the use of terms such as 'Chinese virus'. Findings demonstrate the potential of Weibo as a platform of resistance and site where users contest social injustice and racism, but also as a dangerous space in which populist discourses can yield more populist discourses which influence public sentiment and potentially government policies and international relations.
\end{abstract}

Keywords: counter-discourse, COVID-19, multimodal critical discourse analysis, populism, social media

\section{Introduction}

\subsection{Sino-US Relations and COVID-19}

In recent years, Sino-US relations have gradually shifted from "neither friends nor enemies" to "competitors" since Trump became president in 2017 (Ai, 2020, p.8). Compared to the Obama administration, the Trump administration's policies and strategies towards China were more aggressive and led to increasing Sino-US friction and confrontation particularly in fields such as trade and technology (Whineray, 2020). After the outbreak of COVID-19, Trump and his administration publicly and iteratively used discourses which included Othering of the Chinese people and government (e.g., 'Chinese virus', 'Wuhan virus', 'Kung flu', 'China virus', 'foreign virus'). The Trump administration's populist politics and communication regarding COVID-19 has led to real-world violence against Asian American/Pacific Islander communities in the US (Tessler et al., 2020) as well as heated discussions and debates across various social media sites, including Sina Weibo (aka Chinese Twitter), which has more than 5,000 million active users as of April 2020. In order to understand such communication, it is important to review studies which examine the relationship between social media and populism.

\subsection{Social Media and Populism}

Populism can be understood as "a general protest against the checks and balances introduced to prevent " the people's' direct rule" (Pelinka, 2013, p.3). Its central tenet is the juxtaposition of a (corrupt) political class, elite, or establishment, and 'the people', thus favoring instruments of direct democracy (Greven, 2017, p.1). For Mudde (2004), populism is a 'thin ideology' that focuses on division rather than finding solutions. Laclau (2005) and Mouffe (2018) argue that populism is a way of thinking and talking about the world that is neither right nor left wing. As Hopster notes,

In its typical right-wing variety, the in-group is delineated in terms of national identity, and pitted against immigrants, or ethnic, religious and sexual minorities. In its typical left-wing variety, the in-group is defined in terms of class and pitted against the economic establishment, the privileged ethnic class, or the 'one percent' (2021, p.555).

While left-wing populism can also have emancipatory and progressive aims (e.g., the Occupy Movement in the US) (Gerbaudo, 2018), right-wing populism focuses on Othering, always finding a scapegoat who is seen as a threat to 'our 
nation'. This creates a "politics of fear" (Wodak, 2021, p.6, bolding in the original), which offers simple answers to fears and challenges by constructing the enemy 'Other' as those to blame for our problems while tapping into traditional collective stereotypes and images (Wodak, 2021, p.4). Right-wing politicians often functionalize national identity and nationalism (support for one's nation and its interests) as a way of constructing those who are 'us' and those who do not belong in the group (Wodak, 2021, p.100).

While many of the above studies deal with populism in Euro-American contexts, less attention has been paid to how "the rise of populist ideas echo and reverberate in other regions of the world" (Miao, 2020, p. 268). For example, in the context of China, Miao (2020) suggests that populism and populist ideas differ from their Euro-American counterparts in that elites are viewed not as intrinsically "corrupt or anti-people", but rather endorsers of "the will of the people", and thus they tend to be criticized for failing to fulfill "their paternalistic duty" or their "misuse of power" (p.274). Studies (e.g., Miao, 2020; Zhang, 2020) also show that social media platforms such as Zhihu, i.e., Chinese Quora, have become a breeding ground for Chinese netizens, especially the well-educated, to develop populist discourses, given that opportunities for political involvement offline remain limited because of government regulations and censorship. Meanwhile, social media as such serve as the communication apparatus between Chinese netizens and the Chinese government, with online opinions and appeals shaping the developments and results of sociopolitical events offline (Bi, 2015, as cited in Miao, 2020; Gu, 2014). Therefore, studying and analyzing populist discourses and counter-discourses on social media sites not only helps to unpack the relationship between them, but also demonstrates how online responses could potentially affect real-life issues. It is also important to note that prior to the pandemic, studies such as Miao found much support in China for Trump's populism, casting him as a "fixer of malaise, and a righter of wrongs" (2020, p. 280).

The power of social media has not been lost on populist politicians. Recently, populist movements or candidates such as Nigel Farage in the UK and Donald Trump in the United States have harnessed the power of social media for their own political gain. Gerbaudo (2018, p.746) describes the relationship between social media and populism as an "elective affinity" in which "social media has favoured populist against establishment movements by providing the former a suitable channel to invoke the support of ordinary people against the latter" (Gerbaudo, 2018, p.746). Social media spaces have become places to recruit disaffected citizens (Bartlett et al., 2011) as well as effective channels to express opposition to mainstream media (Gerbaudo, 2018). This "hijacking" of social media by populists has its roots in feelings of betrayal many social media users have against neoliberal forces and their corporations which "promised them a world of connection, entertainment and comfort only to plunge them into economic insecurity" (Gerbaudo, 2018, p.752). According to Gerbaudo (2018, p.747), this widespread discontent caused by the "failings of the neoliberal system" is also largely to blame for the recent global rise in populism.

Hopster (2021, p.556-559) builds on Gerbaudo's idea of an affinity between social media and populism, arguing that there are four important affordances of social media which make it particularly effective for populists. First, social media allows citizens and politicians to circumvent 'establishment' media outlets and filters and be less dependent on journalists as their mouthpiece. Second, social media algorithms are designed in such a way that content is selected not on the basis of journalistic quality standards (which occurred in the previous media ecology), but instead favor content that is popular, as measured by user interaction, viewer duration, and clickthrough (van Dijck et al., 2016, as cited in Hopster, 2021, p.557). Social media also invites a populist style of communication because of 'low-level' affordances such as short length requirements on Twitter and Weibo (which make it easy to create simple messages which is a characteristic of populist discourse), and 'like' buttons which drive emotional appeals, receive a lot of interaction, and reach larger audiences. Finally, social media allows for people to connect to others in real time, share opinions, and hold elite individuals/agencies accountable. All of this gives a sense of empowerment to people. According to Hopster (2021), these affordances are bi-directional. That is, populist politicians and movements benefit from social media, but social media also benefit from populism, and as a result, social media is an object that seems to have "slipped out of the hands of their creators" (Gerbaudo, 2018, p.751). We now turn to the other side of the coin---ways in which people have attempted to use social media as a tool of resistance.

\subsection{Social Media as a Tool of Resistance to Populist Discourse}

Besides studying the way that populist discourses have thrived on social media, scholars have attempted to document how people use it to provide counter-discourses. Brown and Brown (2012, p.11) refer to counter-discourse as "knowledge, theories, and histories that emerge as a direct challenge to commonly held deficit-oriented beliefs about racial groups and social phenomenon". Counter-discourse does not just oppose dominant narratives, it negates assertions by those in power, and provides alternative perspectives (Terdiman, 1985, p.149). People engage in counter-discourse in order to "detect, diagnose, and navigate the codes" by which the dominant discourse naturalizes how we understand the world around us (Terdiman, 1985, p.149), and occupy a space where they can challenge "prevailing authoritative discourses" (Moussa \& Scapp, 1996, p.88). In China, "due to censorship and regulations, 
however, such participation often happens in non-conventional ways" (Miao, 2020, p. 270). Thus, since netizens are unable to comment on domestic politics directly, international politics become popular outlets where opinions are expressed on social media and they offer "valuable insight into how the participants approach politics as a whole" (Miao, 2020, p. 270). In the case of our study, we analyze reactions to external events (e.g., Trump's anti-China discourse) and hence the resistance or counter-discourse acts more as an agent of solidarity against Western hegemony, but also a way for Chinese netizens to express their opinions on international relations with the US directly to the Chinese government via Weibo.

Macgilchrist's (2007) study on counter-discourse in Russia provides a useful framework for analyzing types of counter-discourse, (although it is not directly related to populist discourse). She mentions five counter-discourse strategies utilized in her study; 1) Invert the dominant view by negating it;2) Provide a parody of the discourse in which the style of the dominant discourse is imitated and exaggerated for comic effect; 3) Complicate and provide nuance for the issue by breaking down simplified narratives; 4) Reframe the issue by "reconstruing it within a different set of knowledges"; 5) Radically reframe the issue by blending dialog with other perspectives with inversion of the mainstream perspective (Macgilchrist, 2007, p.76-82).

Another relevant study not directly related to populism but highly relevant to Weibo and counter-discourse is Wu (2018). In this study, the author examined how Weibo users challenged the official discourse on the 2015 Tianjin explosions and how they offered an alternative discourse of the disaster through the Weibo social media platform. The author identifies three main strategies for counter-discourse on Weibo; 1) Resistance by quoting cross-platform accounts by witnesses; 2) Resistance through the creation of rumours; and 3) Resistance through satire/ridicule (Wu, 2018, p.64). These strategies of resistance explained how Chinese netizens "express sociopolitical arguments in non-democratic contexts, and in turn, reshape the power relations between the state and the public" (Wu, 2018, p.64). This is an interesting finding given that Weibo (like other social media in China) is censored by the Chinese government, yet resistance and the highlighting of non-dominant voices thrived on this platform.

Weibo is different from Twitter because of the paradox of the freedom of social media and the restrictions of the state Internet censorship (Gu, 2014). Gu (2014) found that despite state censorship, Weibo can be a potent influencer of government policy/control through the dialogic way in which the Chinese government and its people interact on the platform. Incorporating frameworks of surveillance and the study of freedom of speech, the author shows how Weibo has significantly changed the rapport between the Chinese government and its citizens (e.g., for an example, see Tan [2020] for the way in which Chinese citizens expressed their anger with the Chinese government's silencing of Dr. Li Wenliang on his Weibo page). This has been done by "enabling conversations to occur asynchronously and beyond geographic constraints" (Boyd et al., 2010, p.1). Even though content is filtered for "key sensitive phrases" (Gu, 2014, p.77), "where there is power, there is resistance" (Foucault, 1990, p.95). Hence, Chinese micro bloggers use a variety of strategies to avoid censorship such as proxy servers or VPNs that "bypass censorship" (referred to as "climbing the wall") (Feng \& Guo, 2012, p.10) and they develop code phrases to replace sensitive words in order to get their points across. They also use creativity and humour. Gu's (2014) study also shows how Weibo users work collectively to "raise concerns, express disagreements, and request explanations on policies" (Gu, 2014, p.80), sometimes pushing the "boundaries of associative and communicative freedoms" (Qiang, 2011, p.57). We now review studies that connect social media to Sinophobia post COVID-19.

\subsection{Social Media, Sinophobia, and COVID-19}

Quite a few studies were found that focus on social media, Sinophobia, and COVID-19, most of which concentrated on Twitter, of which the highest percentage of users are based in the US. For example, in Schild et al. (2020), the authors examine the emergence of Sinophobic behavior on the Web during the outbreak of COVID-19. Using data from Twitter and 4chan's Politically Incorrect board (/pol/) over a five month period since the virus first emerged, the authors found a rise in Sinophobic content. This Sinophobic content occurred across multiple platforms, on fringe Web communities but also more mainstream ones such as Twitter. Interestingly, they found more racist slurs on $/ \mathrm{pol} /$ and more instances of blaming China for the virus on Twitter. The authors also found that China's perceived failure to prevent the virus made it an easy target for scapegoating, a phenomenon that is not unique to COVID-19, but rather has been historically shown to be a common strategy in public health crises of the past because it is natural to seek external blame when the world is threatened. Findings also reported that the downside to social media during the pandemic has been the way that it has allowed and encouraged the spread of hateful language "at a time when we can afford it the least" (Schild et al., 2020, p.14). The authors emphasized the need to create "counter-measures with the goal to prevent or mitigate real-world violence stemming from these behaviors" (Schild et al., 2020, p.14).

Another important study that examines racism, hate, and xenophobia on Twitter against Chinese and broader Asian communities and the role of counterhate speech on social media is Ziems et al. (2020). In this study, the authors created 
a dataset of anti-Asian hate and counterhate over a three month period. They found that bots comprised $10.4 \%$ of hateful users and were more vocal than non-bot users. In addition, their network analysis found that there was ample interaction among hateful and counterhate users, and that hateful content bred more hateful content. However, they also found that counterhate messages did play a role in discouraging users from turning hateful in the first place, which does give some hope for resisting populist discourses on social media in the future. Pei and Mehta (2020) also explore racism and xenophobia on social media on Twitter using sentiment analysis in which they track negative sentiment reflected in tweets marked with racist hashtags. The authors conclude by providing policy suggestions for intervention strategies in order to combat racism and xenophobia on social media more effectively. Additionally, Viladrich (2021) critically examines recent literature on stigma and the labeling of COVID-19 as the "Chinese virus" showing how race-based stigma against Asian groups in the United States has been fueled by social media.

A final study worth mentioning is Wang and Catalano (in press). In this study, the authors examined YouTube comments (mostly from users based in the US) responding to Donald Trump's use of the term 'Chinese virus' and other similar terms and his defence of his use of them. In their analysis, they drew on Krämer's (2017) functions of right-wing populism (e.g., spread ideology of 'the people', establish group identity, and construct the 'Other') to show how social media enabled each of the functions in relation to the 'Chinese virus' discourse. They also found that $64 \%$ of commenters agreed with Trump's use of 'Chinese virus' while $34 \%$ of commenters attempted to resist it. Possible reasons listed for such support of Trump included the manipulative power and normalization of populist rhetoric and strategies such as repetition and straw man fallacies. The present study continues the work of Gerbaudo (2018) and Hopster (2021) as well as Wang and Catalano (in press) in order to explore the relationship between social media and populism in the context of COVID-19 from the perspective of Chinese netizens on Weibo.

\subsection{Aims and Research Questions}

As we described above, many scholars have studied the global rise in populism including its causes and functions (e.g., Laclau, 2005; Mudde, 2004; Mouffe, 2018; Wodak, 2021), its symbiotic relationship to social media (e.g., Gerbaudo, 2018; Hopster, 2021), as well as the rise of Sinophobic discourses post COVID-19 (and resistance to these discourses) on social media (e.g., Ziems et al., 2020). However, few studies have explored social media responses in China to Trump's anti-China discourse in the context of the COVID-19 pandemic. To fill this gap, our study focuses on reactions to Trump's populist discourse on Weibo (aka Chinese Twitter) with the aim to shed light on:

1: What is the relationship between social media and populism in the context of the COVID-19 pandemic?

2. How do people respond to populist discourse on social media?

More specifically, we seek to identify what visual and verbal strategies are used to respond to populist discourses and how Trump's anti-China discourse has impacted Chinese netizens' public opinion of the US as well as Sino-US relations. To do so, we rely on tools from critical multimodal discourse analysis which we explain in section 2.2.

\section{Method}

\subsection{Data Collection}

In order to analyze Chinese netizens' responses to Trump and his administration's populist discourse regarding the virus, we examined multimodal data from Sina Weibo, the most popular social media platform in China. Because our paper focuses on reactions to Trump's anti-China discourse, in particular, his use of the term "Chinese virus" or similar terms, we searched the keywords “中国病毒 (Chinese virus)” and “特朗普 (Trump)”, in both Mandarin and English to generate the most trending feeds from Weibo. We then selected three Weibo feeds ${ }^{1}$ which included a video summarizing the timeline of Trump and his administration's 'Chinese virus' discourse and screenshots of Twitter conversations on the same topic, all of which were posted by China Global Television Network (CGTN), a state-owned broadcaster. The rationale behind our selection is twofold: for one thing, the three feeds were the most trending ones we found after conducting a careful and thorough search, meaning that they had a relatively large number of reposts (retweets), comments, and likes, which provide rich data for us to explore; for another, since the feeds mainly feature the Trump administration's anti-China rhetoric, analyzing the comments helps us understand how Weibo users voiced their opinions on and constructed counter-discourses to populist discourses as such. We collected all the comments generated by the three Weibo feeds by May 7th, 2020, i.e., a total of 1,250 multimodal comments (including texts, images, and emojis etc.). Since the comments were mostly written in Mandarin, they were translated into English by Second author (Peiwen).

\subsection{Data Analysis}

We used critical discourse analysis (CDA) to unpack visual and verbal strategies employed by Weibo users to respond 
to Trump's anti-China discourse and his defense of its use. CDA studies language use in order to discover how "dominance, discrimination, power and control" are manifested in language (Wodak \& Meyer, 2016, p.12). In our paper, we incorporate a multimodal approach, which attends to the affordances of different modes of communication. Multimodal approaches to critical discourse analysis (aka MCDA, Machin, 2013; Ledin \& Machin, 2018) are concerned with the way that meaning "shapes (and is shaped by) the social contexts in which it is employed" (Djonov \& Zhao, 2017, p.2) and how different modes (e.g., image, sound, text) work together to produce an overall message. Hence, the theories and tools from the field of multimodality enable us to "understand and account for the world of communication as it is now" (Kress, 2010, p.7). We employ MCDA to make sense of the way that Weibo users incorporate emojis, memes, and other modes to change/add to/embellish/emphasize their communication. We also use MCDA to help us break down (and understand the consequences of) multimodal metaphor/metonymy (Forceville \& Urios-Aparisi, 2009) occurring when texts and images work together to produce a metaphor or metonymy (e.g., when one element stands for another element it is closely related to or associated with) (Littlemore, 2015). Our analysis will explain how these multimodal metaphors work as strategies to respond to populist discourses.

The data analysis occurred in several stages. It began with an initial coding of the 1,250 Weibo comments as we highlighted salient themes emerging from the data (e.g., labelling Trump's strategies, conspiracy theories, vulgarities/insults). We then eliminated comments deemed as irrelevant (e.g., comments about learning English) as well as those that were previous comments shared or re-tweeted, and any comments that did not appear to be a reaction to the original Tweets of Donald Trump. Next, we uploaded the remaining comments (including multimodal data such as emojis) to MAXQDA 2020 qualitative software analysis program and Peiwen coded them grouping them according to discursive strategies used, leaving uncoded any comments she was unsure of how to categorize. Once initial strategy codes were established, we (both authors) met to discuss the codes and determine categories together which Peiwen was unsure of. After this step, we reviewed and refined other codes as well as names of the strategies. In order to identify/name strategies used, we referred to literature such as Wodak (2021) and other work that specializes in analysis of populist discourse (e.g., Fielder \& Catalano, 2017; Sengul, 2019; Wodak et al., 2009). For example, if the initial code was "sarcasm", we then reexamined the context and found that the sarcasm was used as an indirect way to resist/oppose the dominant view, and so we referred back to the literature and categorized it as "counter the dominant view" (see Macgilchrist, 2007). We also found other ways in which the dominant view was countered and so we included these as means of realization for that same strategy. This was done systematically with each example from the threads we examined. Table 1 (adapted from Wodak et al., 2009), which we discuss in the next section, lists the final categories of strategies that were determined from the analysis.

\section{Findings and Discussion}

We will now discuss the way in which Weibo users responded to Trump's populist anti-China discourse. Table 1 depicts the following four main strategies found in the data: 1) Counter the dominant view, 2) Establish the 'Other', 3) Label Trump's strategies and explain their purpose, and 4) Appeal to national unity/solidarity and build community.

Table 1. Visual and Verbal Strategies to Respond to 'Chinese Virus' Discourse

\begin{tabular}{|c|c|c|c|}
\hline No. of Comments & Likes & Strategy/Example & Means of Realisation \\
\hline $454(54.8 \%)$ & 2634 & $\begin{array}{l}\text { 1. Counter the dominant view } \\
\text { (e.g., The World Health Organization } \\
\text { has not labeled it the Chinese virus). }\end{array}$ & $\begin{array}{l}\text { sarcasm, parody, irony, } \\
\text { (via multimodal metaphor/ } \\
\text { metonymy), inverting, } \\
\text { negating, providing } \\
\text { alternative perspectives }\end{array}$ \\
\hline $181(21.9 \%)$ & 110 & $\begin{array}{l}\text { 2. Establish the "Other" } \\
\text { (e.g., Motherfxxker) }\end{array}$ & $\begin{array}{l}\text { conspiracy theories, } \\
\text { derogatory/disparaging language, } \\
\text { profanity, emojis, } \\
\text { memes (via } \\
\text { metaphor/metonymy) }\end{array}$ \\
\hline $162(19.6 \%)$ & 4042 & $\begin{array}{l}\text { 3. Label Trump's strategies, } \\
\text { explain their purpose, } \\
\text { ( e.g., Passively react to COVID-19 } \\
\text { and then scapegoat China. } \\
\text { Shameless. }\end{array}$ & $\begin{array}{l}\text { intertextuality, } \\
\text { deixis/vocative } \\
\text { (to directly speak to Trump), } \\
\text { matching academic/formal } \\
\text { terms to Trump's } \\
\text { words/actions }\end{array}$ \\
\hline $28(3.3 \%)$ & 105 & $\begin{array}{l}\text { 4. Appeal to national unity/ } \\
\text { solidarity, build community } \\
\text { (e.g., I feel so proud of China..) }\end{array}$ & $\begin{array}{l}\text { nationyms, information on } \\
\text { virus, response in China, } \\
\text { deixis, direct calls for activism }\end{array}$ \\
\hline
\end{tabular}


We will now examine each of the strategies found in the discourse, provide examples of each, and explain how they are realized on Weibo.

\subsection{Alternative Perspectives/Inverting the Dominant View}

The first strategy found was to counter the dominant view. Counter-discourse in our data was commonly realized via humor (e.g., sarcasm, irony, parody) often expressed as multimodal metonymy or metaphor, and by inverting or negating the dominant view and providing alternative ways of perceiving of the situation (as found in Macgilchrist, 2007). Counter-discourse which attempted to resist Trump's use of 'Chinese virus' and his defense of the term consisted of 54.8\% of the data. Note that in our case, the counter-discourse was targeted at Chinese people but also the Chinese government. Our data aligns with Gu's (2014) study which found creativity and humor to be an important strategy of resistance on Weibo and metonymy and metaphor were important elements of how this humor was produced. Metonymy is when one thing stands for another it is closely related to or associated with. It is also (along with metaphor) a way in which we reason about and understand our world (Catalano \& Waugh, 2013). In Example 1), Trump is sarcastically referred to as 建国 (Jianguo), which originally means "building a nation (China)" in Mandarin and connotes patriotism.

1) 建国 (Jianguo) wants to turn the current domestic conflict into an international one? Nice distraction ${ }^{2}$.

The metonymy of 建国 (Jianguo) was frequently found in the data because Chinese netizens believed that Trump's decisions or policies were in effect detrimental to the US but beneficial to China, thus contributing to the construction of China (Hu, 2020). They therefore ironically called Trump Jianguo, which inverts Trump's status as the President of the United States and imagines him working (covertly) for China. This example not only mocks Trump but it incisively points out Trump's real political agenda behind the 'Chinese virus' rhetoric, namely, diverting attention from the domestic chaos resulting from his incompetence. The hand gesture depicted in the emoji in example 1) derives from a gesture to show Chinese people's respect for "师父 shifu (master)" in ancient times and indicates a sense of admiration or honoring of others. In this case, however, the hand gesture emoji is used frequently by commenters to ironically express a sarcastic respect for Trump's strategy of distracting from his own botched handling of the coronavirus in the US by blaming China.

Besides using humor and creative uses of emojis, many commenters also used counter-discourse strategies such as those described in Macgilchrist (2007). Example 2) refers back to the history in which the Spanish Flu was named as such yet later its origins were suspected to be in Kansas, in the US.

2) The Spanish pandemic flu 100 years ago had the first outbreak in the United States, but continuous reports in the Spanish media made everyone mistakenly believe that it was an outbreak in Spain.

This example demonstrates Macgilchrist's (2007) strategy of resistance in which the dominant view (put forth by Trump) is complicated, and nuance is provided for the issue by breaking down the simplified narrative in which Trump defends his use of 'Chinese virus' by saying "It comes from China" (Wang \& Catalano, in press). Here the commenter points out how the previous pandemic was mistakenly named after Spain. In the next example, the commenter negates the dominant view that the virus originated in China, and then reframes the issue providing "a different set of knowledges" (Macgilchrist, 2007, p.80).

3) No matter where the virus originated, it has always been the opposite of all humanity. China has made so many efforts but has been stigmatized. Some countries have been too malicious toward China. Besides, China might not be the place of origin. Even so, China has been helping the whole world to get through this. Looking at the practice of some countries, however, they were acting like an outsider and watch other countries suffer, but when the virus breaks out, they continue seeking help while scapegoating...

Example 3) points out the stigmatizing effect this term has had on China, the role China has had in helping other countries combat the virus, and the inaction of other countries to China's suffering until their own people began to suffer. Incidentally, in 2015, the World Health Organization banned the naming of diseases after people, places, and animals due to the "unintended negative impacts by stigmatizing certain communities or economic sectors" (WHO, 2015), but Trump ignored that in his use of 'Chinese virus'. Example 4) which also provides counter-discourse, makes this point:

4) The World Health Organization has not labeled the virus as Chinese virus. The president has personally taken the lead and incited public opinion to try to discredit China.

It is clear from the above examples that Weibo users have no doubts as to the reasons why Trump used the term 'Chinese virus' and as $\mathrm{Gu}$ (2014), Wu (2018) and others have shown, Chinese netizens use Weibo as a public space in which they can work collectively to express their opinions or disagreements, even though they do not expect that their comments will be read by President Trump. However, it is worth noting that we did not find any comments that agreed with Trump's use of 'Chinese virus' or his critique of the Chinese government but it is possible (but not likely) that these comments did exist, but were deleted in the censorship process. 


\subsection{Establishing the 'Other'}

Othering is a common strategy used in right-wing/far-right populist discourse (Wodak, 2021) in which group members aim to differentiate 'us' from 'them' by first establishing a positive 'us' and then show how 'they' are different, through the attribution of negative traits. Trump utilized this strategy by continually associating COVID-19 with China and accusing the Chinese government of negligence in informing the world about the virus as evidence of the way they are different from 'us'. In the case of our data, $21.9 \%$ of comments reciprocated this same strategy to respond to Trump's discourse by Othering Trump and the United States government. In this way, far-right populist discourse begets more of the same. This finding aligns with Zhang's (2020, p. 88) study in which the author found that Chinese internet users appropriated the rhetoric of "Western-style' right-wing populism", in this case, they used it as a way to build community and unite against Trump and the US. This was accomplished by using disparaging/derogatory words to refer to Trump and his administration, spreading conspiracy theories about the US's role in the pandemic, and using profanity/vulgarities directed at Trump, all of which emphasized a negative them'. Example 5) shows how America becomes a metaphor for disease in the way that China was in Trump's discourse.

\section{5) America is the virus in the world!}

Similarly, example 6), depicts Trump as a coronavirus with blonde hair and the capitalized letters "INCOMPETENCE" on his face.

6)

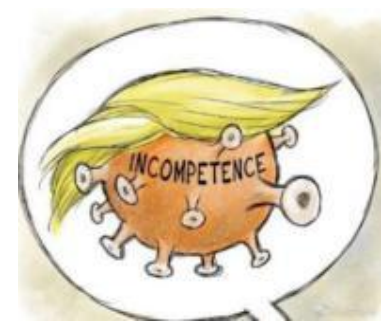

The metonymies (blonde hair, orange colour) help the viewers understand that the image is supposed to be Trump, even though it never says Trump's name. The spikes on the orange ball are metonymic for the coronavirus, which ring the body of the virus like a jeweled crown (hence the name 'coronavirus'). These metonymies then motivate the metaphor TRUMP IS A VIRUS. This multimodal metaphor (because the text and the image work together to create the metaphor) is powerful as it directly challenges Trump's discourse by turning him into a virus, and simultaneously criticizing his lack of competence in containing the virus through use of the word "INCOMPETENCE" in capital letters.

The next example shows how conspiracy theories were used by some Weibo users to Other the US (similar to what Wang \& Catalano, [in press] found) by pointing out negative characteristics in terms of being responsible for the virus:

7) It originated from the United States, patient zero spread the virus from the United States to Wuhan through the Military Games, thank you for bringing the virus to the world...

In this case, the comment refers to patient zero, which stands for the person who was identified to be the first person infected and claims this person was a US soldier that attended the military games at the end of 2019, and like many conspiracy theories about the coronavirus having origins in a lab in Wuhan, there is still no evidence that this theory is true. Interestingly, the metonymy patient zero seems to be related to the term 'ground zero', which is a starting place for a particular activity, but in the US since 9/11, this has come to be associated with the terrorist attacks on September 11, 2001 , since the place where the twin towers fell is still referred to as 'ground zero'. The comment ends with a sarcastic thank you for bringing the virus to the world which simultaneously turns the tables and blames the virus on the United States.

A final strategy of Othering was through the use of vulgarity/profanity (also known as swearing), which is linked to incivility. These expletives serve the function of expressing emotions and intensifying their impact, which often means they get more traction on social media. Interestingly, comments that used this strategy did not get nearly as many 'likes' as those that labeled Trump's strategies explicitly, which we will discuss in the next section. Below are a few examples of the types of profanity used, mainly directed at Trump, but sometimes at America in general.

8) fxxk u, American cancer

9) Please allow me to say this sentence (which is just what he needs): FUCK

OFF

10) Motherfxxker

According to Song et al. (2020, p.982), the use of profanity or foul language has become increasingly common in digital 
spaces and on Weibo, the authors found that swearing posts generally were shared more often and created chain reactions that became contagious. Kwon and Gruzd (2017) have shown how swear words serve as high-arousal emotional markers when other non-verbal cues are absent and can function as speech acts which provoke further anger and verbal aggression in commenters. In this way, a 'spillover effect' occurs in which subsequent users adopt the swearing style of previous users. Our data did not show this 'spillover effect' in which one person's profanity was followed by more of the same, but we did find a general tendency for disparaging/derogatory comments of any kind (whether they included profanity or not) to yield more of the same. Additionally, we did not find that the use of profanity dominated the data (only 21.9\%) nor did these comments receive the most likes from others (see Table 1).

Interestingly, we found that when commenters used profanity, they attempted to mitigate its effect in several ways. One way was to strategically use different Chinese characters or English words that have similar sounds to the profanity as in examples 8) and 10) which we translated by inserting an " $\mathrm{x}$ " in the English word so the original spelling was not shown (original Chinese tweets were “曹尼玛, 美国癌症” and “踏马的”). Another way this was done was to insert the image of a horse in place of the full swear word since the words for 'horse' and 'mother' sound the same (马 and 妈) (except for the tone).

\section{1) 你理解你呢}

[you understand you motherfxxker]

Another strategy found was to use the initial letters of the Pinyin of the Chinese swear words such as in this example in which tmsl stands for "ta ma si la" (他妈死了) which insults Trump by saying his mother is dead.

\section{2) 把自己的无能通通电锅中国人!! 堂堂总统带头歧视 tmsl}

[Scapegoating the Chinese to cover his own incompetency!!! The president takes the lead to discriminate motherfxxker].

There are several possible reasons for these mitigation strategies. The most obvious is to avoid being deleted by the platform or CGTN who posts the feeds since the Chinese government's "demand for civility" on social media has led to censuring of profanity on Weibo. According to Song et al., (2020, p.985), Chinese authorities have publicly problematized the lack of civility in the nation's digital culture and have conveniently used this as a justification for state control over the digital platforms. Another possible explanation for these mitigation strategies is to appear less confrontational or vulgar while achieving the same emotional response and effect of Othering. Note that many of these expressions would be more likely understood by Chinese mainland citizens as opposed to those from Hong Kong or Taiwan, and since in some cases there are English words incorporated, they are more likely to be recognized by younger Weibo users.

\subsection{Labeling Trump's Strategies/ Explaining Their Purpose}

The next most used strategy in the data was that of labeling Trump's strategies and explaining their purpose (19.6\% of comments). This was accomplished through intertextuality (shaping the meaning of a text by incorporating other texts) in which users shared memes and other tweets from other platforms, use of deixis (words such as pronouns that are used for purposes of positioning)/vocatives (words like pronouns that invoke people or things) to address Trump directly, and matching academic or formal terminology to Trump's actions or words. In example 13), Weibo users re-tweet memes from other platforms that label what Trump is doing with the 'Chinese virus' discourse and explain why he uses racism as a strategy.

\section{Racism \\ is Not \\ the Right Tool \\ to Cover \\ Your Own \\ Incoinpetence}

Interestingly, many of these memes (as in example 13) were taken from other sites and posted on Weibo where users worked together to translate them for each other. Example 13) clearly shows how commenters not only perceive the use of 'Chinese virus' as racist, but they also understand the underlying reasons why Trump uses the term (i.e.., to distract 
from his own incompetence in handling the virus). In the next example, the user is fully aware of framing as a rhetorical device, matching the academic word for the social construction of a social phenomenon to Trump's use of 'Chinese virus'.

\section{4) Framing is not going to get your country through this.}

Example 14) also illustrates how many Weibo users often wrote as if they were speaking directly to Trump. This is seen by the use of the deixis your which acts as a vocative, addressing Trump as if he is reading the comment and listening to the commenter. In this way, it is clear that the commenter views Weibo as a populist venue in which 'the people' can really have a voice and make a difference, a finding noted in Wu (2018). In many examples like this, it is as if the Weibo users believe that their comments constitute activism and that they are actually creating social change through their comments (see also example 15), next section). However, this is not the case since Trump does not know Mandarin (the language of the original tweet), and it is doubtful that he reads Weibo. In addition, as Alperstein and Jones (2020) have noted, activism must be more than just commenting online- it must be accompanied by in person marches and protests and large-scale events in which the cause can be furthered. So, while those tweeting may feel as if they are fighting for social justice through their comments, it does not always result in actual change. However, even though this 'clicktivism' can sometimes do less than people hope or believe it does (Halupka, 2018), it can at least result in bringing important issues into the public eye (Bouvier \& Machin, 2021), and in the case of Weibo, to the Chinese international policymakers which users believe could be influenced by their online activism.

\subsection{Appealing to National Unity/Solidarity/Building Community}

Gruzd et al. (2018) found that digitally based social networks sometimes develop as imagined communities dispersed geographically who coalesce around a particular cause or issue. However, unlike traditional communities, members of a virtual community do not have to know one another, and they are not limited by geography or other factors (Alperstein \& Jones, 2020). Such is the case for our study. Our fourth strategy of responding to Trump's discourse is to appeal to national unity/solidarity and build community. This strategy was realized by making direct calls for activism to respond to Trump's populist discourse, and through the process of nationalization, which is when an in-group categorizes people according to their nationality. This was accomplished largely by use of deixis and/or nationyms (i.e., China, Chinese, America). Example 15) illustrates how Chinese netizens co-opted Weibo as a site for activism to combat anti-China/Chinese sentiment.

\section{5) Why can't this Weibo post trend in Weibo? Trump calls it Chinese Virus, can't we just fight back? @ Weibo Trending Rank}

Above, the user refers people to the site that counts Weibo trends, recognizing that tweets that trend call more public attention to the issue. In addition, the commenter speaks directly to other commenters using the deixis we to put users in the same space, and to build community in that space. The next comment demonstrates how social media can sometimes be a place where people can cope with discrimination/racism, and oppression, and a space to feel solidarity with others.

\section{6) I felt less lonely when I heard so many righteous voices from abroad...}

It is interesting that although the comment was posted on the Weibo platform, the user makes connections to Twitter users whose tweets are re-posted on Weibo. In this way, although Weibo is a separate platform and subject to censorship and monitoring by the Chinese government, there is a sense that through re-tweets and posting from Twitter to this platform, it does connect Weibo to a larger, more global community, which in turn, helps the commenter feel better about the discourse, and feel part of a community rather than alone.

Despite comments such as example 16) which showed how Weibo was used as a coping mechanism against populist discourse, we also found that Trump's nationalist discourses against China had a similar 'rally around the flag' effect in China (Bruno et al., 2020), as seen in this comment:

17) The Chinese people are great people. They care about the world and look at the world! Now there is another anti-American frenzy! Anti-American frenzies can boost the spirit.

Example 17) lays out clearly a positive 'us' (e.g., Chinese people) which benefits from anti-American sentiment which can boost the spirit. In this way, the populist discourse of Trump leads Weibo users to feel more solidarity and pride toward the Chinese government, resulting in more public support for China-friendly policies while at the same time generating anti-US sentiment. In this way, many comments acted as if in dialog between the Chinese people and/or government, which aligns with Gu's (2014) and Zhang's (2020) work which posit that this discourse can reimagine national identity and self-other relations in new ways. As such, when users criticize Trump's populist discourse, they reconstruct China's ethno-racial identity and position China's political identity against "the 'declining' Western other" 
(Zhang, 2020, p. 90).

In our next examples, we show how Trump's populist discourse lent support for nationalist policies and ideologies in China. For instance, the commenter in example 18) uses profanity while ironically implying that China will not send masks to the United States who at the time of this posting, was experiencing a scarcity of them.

\section{8) Fxxk off, no masks for sale}

The commenter also uses the smiley face emoji to lend a sense of irony and jocular tone. Example 19) (and many others like it) reinforces the notion that China should not help the United States.

\section{9) Never ever help them!}

Note the use of the imperative form (e.g., Never ever help...) and the deixis them, to further establish the in and out-group and create distance between them, which is a common strategy that Wodak (2021) and others have noted as prevalent in populist discourse. Our final example again communicates with the Chinese people and/or government explicitly requesting no help or exporting of goods to the US.

\section{0) Don't help or export to US, safeguard our own land, and help other}

\section{countries.}

This example employs the argument (or topos, as referred to by Wodak, 2021) of culture or threat in which our own land needs to be protected from the threat of the United States. In fact, nativist ideologies such as these which denote a need to protect one's country from foreign threats are common in far-right populist discourses.

\section{Conclusion}

In this study we examined the relationship between social media and populism in the context of the COVID-19 pandemic including how Weibo users have responded to populist discourse on social media. Previous studies (e.g., Miao, 2020) have found support in China for Trump's populism. It is not surprising however that our findings show the opposite, given the anti-China content of the discourse of study. Instead, our findings reveal that Weibo commenters largely contested and disagreed with Trump's populist discourse and utilized four main strategies to respond; 1) Counter the dominant view, 2) Establish the 'Other', 3) Label Trump's strategies and explain their purpose, and 4) Appeal to national unity/solidarity and build community. Weibo was found to be an effective site of resistance during the pandemic when anti-China/Chinese sentiment has increased dramatically. This is because the affordances provided by social media platforms such as Weibo enabled citizens to voice their opinions, to participate in the larger global conversation, and seek positive change by influencing their government's US policy. Our data showed that Weibo users successfully challenged and disrupted the dominant discourses built by Trump and his administration regarding their communication about COVID-19. They did so largely through use of creativity and humor (as found in Gu, 2014) and through the process of multimodal metonymy/metaphor such as in the ironic use of Jianguo to refer to Trump, and by negating the populist discourse and proposing alternative perspectives.

However, there was nuance to our analysis. We also found that Weibo was a space in which populist discourses bred more populist discourses, fueling Chinese nationalist and anti-US sentiment. The affordances of Weibo which included being able to send emojis and post links to other articles or screenshots of tweets/memes/videos from other platforms allowed users multiple means of realizing their strategies to respond to Trump's discourse. In particular, they used derogatory language/images and profanity to 'Other' Trump and the US government or conspiracy theories that depicted a negative 'them'. They also used the vocative case as if directly speaking to Trump and calling out the strategies he used and matching them to Trump's words and actions (e.g., racism, scapegoating, framing). Finally, we found that Trump's populist discourse stoked nationalist sentiments that encouraged anti-US comments and sentiment, and a general backlash against helping the US. Although we do not know if anti-American sentiments expressed in response to Trump influenced Chinese government policies and willingness to help the US, Weibo does provide a glimpse as to how Trump's populist discourse has helped the Chinese government build support for its pandemic policies as well as in general, while at the same time downplay/background its own deficiencies in its initial response to the virus.

Our study is limited in that we only analyzed one issue (Trump's use of 'Chinese virus'), and the responses to it based on three Weibo feeds. Hence, we encourage further study of Weibo, populism, and other social issues with larger data sets in order to be able to make generalizations about user reactions to populist discourses. In addition, we suggest further studies explore how social media can be regulated in a way that prevents populist discourses from causing harm to society (e.g., violence against Chinese and Asian Americans/Pacific Islanders in the US). As Gerbaudo (2018) notes, it is clear that social media will continue to play a central role in conflict between the establishment and 'the people', and because social media and populism mutually benefit each other (Hopster, 2021), we must consider ways to make 
social media a less friendly space for populist discourses to thrive, or we will continue to see its influence in global politics in the future.

\section{Funding}

This publication was made possible by the Nebraska Tobacco Settlement Biomedical Research Development Funds and the University of Nebraska-Lincoln Office of Research and Economic Development. Authors also received administrative support from the Nebraska Center for Research on Children, Youth, Families and Schools.

\section{References}

Ai, X. (2020). Trump Administration's Foreign Policy toward China. Master's Thesis, Charles University, Czech.

Alperstein, N., \& Jones, T. (2020). The Online Social Movement of\# NeverAgain: How social networks build a sense of membership, influence, support and emotional connection on Twitter. The Journal of Social Media in Society, 9(2), 127-149. Retrieved from https://www.thejsms.org/index.php/JSMS/article/download/599/375

Bartlett, J., Birdwell, J., \& Littler, M. (2011). The new face of digital populism. Demos.

$\mathrm{Bi}, \mathrm{H}$. (2015). The principal features of online public opinion. Social Sciences in Guangxi, September, 1-4.

Bouvier, G., \& Machin, D. (2021). What gets lost in Twitter 'cancel culture' hashtags? Calling out racists reveals some limitations of social justice campaigns. Discourse \& Society, 32(3), 307-327. https://doi.org/10.1177/0957926520977215

Boyd, D., Golder, S., \& Lotan, G. (2010). Tweet, tweet, retweet: Conversational aspects of retweeting on Twitter. In Proceedings of HICSS-43: Hawaii International Conference on System Sciences, 1-10. Kauai, HI: IEEE. https://doi.org/10.1109/HICSS.2010.412

Brown, K. D., \& Brown, A. L. (2012). Useful and Dangerous Discourse: Deconstructing Racialized Knowledge about African-American Students. Educational Foundations, 26, 11-26. Retrieved from: https://files.eric.ed.gov/fulltext/EJ968815.pdf

Bruno, V. A., Downes, J. F., \& Scopelliti, A. (2020). The aftermath of the constitutional referendum in Italy: Stability for the conte executive, Lega on the decline \& Fratelli d'Italia on the rise? Retrieved from http://www.radicalrightanalysis.com/2020/10/14/the-aftermath-of-the-constitutional-referendum-in-italy-stability-f or-the-conte-executive-lega-on-the-decline-fratelli-ditalia-on-the-rise/

Catalano, T., \& Waugh, L. (2013). The ideologies behind crime reports of Latinos and Wall Street/CEOs: A Critical Analysis of Metonymy in text and image. Critical Discourse Studies, 10(4), 406-426. https://doi.org/10.1080/17405904.2013.813774

Djonov, E., \& Zhao, S. (2017). Social Semiotics: a Theorist and a Theory in Retrospect and Prospect. In: Zhao S et al. (eds) Advancing multimodal and critical discourse studies: Interdisciplinary research inspired by Theo Van Leeuwen's social semiotics. Routledge, pp.1-17. https://doi.org/10.4324/9781315521015-1

Feng, G., \& Guo, Z. (2012). Tracing the route of China's Internet censorship: An empirical study. Telematics and Informatics. https://doi.org/10.1016/j.tele.2012.09.002

Fielder, G., \& Catalano, T. (2017). Othering others: Right-wing populism in UK media discourse on "new" immigration. In J. Chovanec and K. Molek-Kozakowska (Eds.), Representing the Other in European Media Discourses. (pp. 207-234). London/New York: John Benjamins.

Forceville, C., \& Urios-Aparisi, E. (eds) (2009). Multimodal Metaphor (Vol. 11). Walter de Gruyter. https://doi.org/10.1515/9783110215366

Foucault, M. (1990). The History of Sexuality, Vol.1: An introduction. Vintage.

Gerbaudo, P. (2018). Social media and populism: an elective affinity?. Media, Culture \& Society, 40(5), 745-753. https://doi.org/10.1177/0163443718772192

Greven, T. (2017). Right-wing populism and authoritarian nationalism in the US and Europe. Friedrich-Ebert-Stiftung.

Gruzd, A., Haythornthwaite, C., Paulin, D., Gilbert, S., \& Del Valle, M. E. (2018). Uses and gratifications factors for social media use in teaching: Instructors' perspectives. New Media \& Society, 20(2), 475-494. https://doi.org/10.1177/1461444816662933

Gu, Q. (2014). Sina Weibo: A Mutual Communication Apparatus between the Chinese Government and Chinese Citizens. China Media Research 10, no. 2. Retrieved from http://web.b.ebscohost.com/ehost/pdfviewer/pdfviewer?vid=0\&sid=f59eb156-d36f-4f15-9f7d-3a55965928c4\%40p 
dc-v-sessmgr02

Halupka, M. (2018). The legitimisation of clicktivism. Australian Journal of Political Science, 53(1), 130-141. https://doi.org/10.1080/10361146.2017.1416586

Hopster, J. (2021). Mutual affordances: the dynamics between social media and populism. Media, Culture \& Society, 43(3), 551-560. https://doi.org/10.1177/0163443720957889

Hu, Y. (2020). Chinese Netizens Discuss US Politicians Using Telltale Nicknames. Global Times. June 4th. Retrieved from: https://www.globaltimes.cn/content/1190628.shtml

Krämer, B. (2017). Populist online practices: the function of the Internet in right-wing populism. Information, Communication \& Society, 20(9), 1293-1309. https://doi.org/10.1080/1369118X.2017.1328520

Kress, G. (2010). Multimodality: A Social Semiotic Approach to Contemporary Communication. Routledge.

Kwon, K. H., \& Gruzd, A. (2017). Is offensive commenting contagious online? Examining public vs interpersonal swearing in response to Donald Trump's YouTube campaign videos. Internet Research, 27(4), 991-1010. https://doi.org/10.1108/IntR-02-2017-0072

Laclau, E. (2005). Populism: What's in a Name?. Populism and the Mirror of Democracy 48. Retrieved from http://scholarworks.unr.edu:8080/bitstream/handle/11714/117/empire_terror-web.pdf?sequence=1\&isAllowed=y\#p age $=104$

Ledin, P., \& Machin, D. (2018). Doing visual analysis: From theory to practice. Sage.

Littlemore, J. (2015). Metonymy. Cambridge University Press. https://doi.org/10.1017/CBO9781107338814

Macgilchrist, F. (2007). Positive Discourse Analysis: Contesting Dominant Discourses by Reframing the Issues. Critical Approaches to Discourse Analysis Across Disciplines 1, no. 1:74-94. Retrieved from https://www.academia.edu/616573/Positive_Discourse_Analysis_Contesting_Dominant_Discourses_by_Reframin g_the_Issues

Machin, D. (2013). What is multimodal critical discourse studies? Critical discourse studies, 10(4), 347-355. https://doi.org/10.1080/17405904.2013.813770

Machin, D., \& Mayr, A. (2012). Critical Discourse Studies: A Multimodal Approach. Sage.

Miao, Y. (2020). Can China be populist? Grassroot populist narratives in the Chinese cyberspace. Contemporary Politics 26(3), 268-287. https://doi.org/10.1080/13569775.2020.1727398

Mouffe, C. (2018). For a left populism. Verso Books.

Moussa, M., \& Scapp, R. (1996). The Practical Theorizing of Michel Foucault: Politics and Counter-Discourse. Cultural Critique, (33), 87-112. Retrieved from: https://doi.org/10.2307/1354388

Mudde, C. (2004). The populist zeitgeist. Government and opposition, 39(4), 541-563. https://doi.org/10.1111/j.1477-7053.2004.00135.x

Pei, X., \& Mehta, D. (2020). \# Coronavirus or\# Chinesevirus?!: Understanding the negative sentiment reflected in Tweets with racist hashtags across the development of COVID-19. arXiv preprint arXiv:2005.08224.

Pelinka, A. (2013). Right-wing populism: Concept and typology. Right-wing populism in Europe: Politics and discourse, $3-22$.

Qiang, X. (2011). The Battle for the Chinese Internet. Journal of Democracy, 22(2), 47-61. https://doi.org/10.1353/jod.2011.0020

Republic. Retrieved from https://dspace.cuni.cz/bitstream/handle/20.500.11956/119247/120361239.pdf?sequence=1

Schild, L., Ling, C., Blackburn, J., Stringhini, G., Zhang, Y., \& Zannettou, S. (2020). "Go eat a bat, chang!": An early look on the emergence of sinophobic behavior on web communities in the face of covid-19. arXiv preprint arXiv:2004.04046. Retrieved from https://arxiv.org/pdf/2004.04046.pdf

Sengul, K. (2019). Critical discourse analysis in political communication research: a case study of right-wing populist discourse in Australia. Communication Research and Practice, 5(4), 376-392. https://doi.org/10.1080/22041451.2019.1695082

Song, Y., Kwon, K. H., Xu, J., Huang, X., \& Li, S. (2021). Curbing profanity online: A network-based diffusion analysis of profane speech on Chinese social media. New Media \& Society, 23(5), 982-1003. https://doi.org/10.1177/1461444820905068 
Tan, Y. (2020). Li Wenliang: 'Wailing Wall' for China's virus whistleblowing doctor. Retrieved from https://www.bbc.com/news/world-asia-china-53077072

Terdiman, R. (1985). Discourse/Counter-discourse: The Theory of Symbolic Resistance in Nineteenth Century France. Cornell University Press.

Tessler, H., Choi, M., \& Kao, G. (2020). The anxiety of being Asian American: Hate crimes and negative biases during the COVID-19 pandemic. American Journal of Criminal Justice, 45(4), 636-646. https://doi.org/10.1007/s12103-020-09541-5

van Dijck, J., Poell, T., \& De Waal, M. (2016). De Platformsamenleving. Strijd om Publieke Waarden in een Online Wereld. Amsterdam University Press. https://doi.org/10.5117/9789462984615

Viladrich, A. (2021). Sinophobic stigma going viral: Addressing the social impact of COVID-19 in a globalized world. American Journal of Public Health, 111(5), 876-880. https://doi.org/10.2105/AJPH.2021.306201

Wang, P., \& Catalano, T. (in press). Social media, right-wing populism, and COVID-19: A multimodal critical discourse analysis of reactions to the "Chinese Virus" discourse. In A. Musolff, R. Breeze, K. Kondo, and S. Vilar-Lluch (Eds.), Pandemic and Crisis Discourse. London: Bloomsbury Linguistics.

Whineray, D. (2020). The G2 at the UN: United States and the People's Republic of China at the United Nations Before COVID-19. New York: United Nations University: 2020. Retrieved from http://collections.unu.edu/eserv/UNU:7666/Whineray_USChina.pdf

Wodak, R. (2021). The Politics of Fear: The Shameless Normalization of Far-Right Discourse. Sage.

Wodak, R., \& Meyer, M. (2016). Critical Discourse Studies: History, Agenda, Theory and Methodology. Methods of Critical Discourse Studies (2nd ed.), ed. by Ruth Wodak and Michael Meyer, pp.1-22. Sage. https://doi.org/10.4324/9781315304670-21

Wodak, R., de Cillia, R., \& Reisigl, M. (2009). The Discursive Construction of National Identity (2 ${ }^{\text {nd }}$ ed.). Transl. by Angelika Hirsch, Richard Mitten and J. W. Unger. Edinburgh University Press.

World Health Organization (2015). WHO issues best practices for naming new human infectious diseases. Retrieved from https://www.who.int/news/item/08-05-2015-who-issues-best-practices-for-naming-new-human-infectious-diseases

Wu, X. (2018). Discursive Strategies of Resistance on Weibo: A Case Study of the 2015 Tianjin Explosions in China. Discourse, Context \& Media, 26(2018), 64-73. https://doi.org/10.1016/j.dcm.2018.05.002

Zhang, C. (2020). Right-wing populism with Chinese characteristics? Identity, otherness and global imaginaries in debating world politics online. European Journal of International Relations, 26(1), 88-115. https://doi.org/10.1177/1354066119850253

Ziems, C., He, B., Soni, S., \& Kumar, S. (2020). Racism is a virus: Anti-Asian hate and counterhate in social media during the covid-19 crisis. arXiv preprint arXiv:2005.12423. Retrieved from: https://arxiv.org/pdf/2005.12423.pdf

\section{Notes}

Note 1. Selected feeds from Weibo include the following:

https://m.weibo.cn/3173633817/4483399970501688

https://m.weibo.cn/3173633817/4483450595946019

https://m.weibo.cn/3173633817/4486345420750263

Note 2. Bolded words in examples were bolded by the authors to denote words of focus in the analysis.

\section{Copyrights}

Copyright for this article is retained by the author(s), with first publication rights granted to the journal.

This is an open-access article distributed under the terms and conditions of the Creative Commons Attribution license which permits unrestricted use, distribution, and reproduction in any medium, provided the original work is properly cited. 